\title{
Historical Consciousness Among Millennial Generation
}

\author{
$1^{\text {st }}$ Umasih $^{1}$, \\ History Education Study Program \\ Universitas Negeri Jakarta \\ East Jakarta, Indonesia \\ umasih@unj.ac.id
}

\author{
$2^{\text {nd }}$ Kurniawati $^{2}$, \\ History Education Study Program \\ Universitas Negeri Jakarta \\ East Jakarta, Indonesia \\ kurniawati@unj.ac.id
}

\author{
$3^{\text {rd }}$ M. Fakhruddin ${ }^{3}$ \\ History Education Study Program \\ Universitas Negeri Jakarta \\ East Jakarta, Indonesia \\ mfakhruddin@unj.ac.id
}

\begin{abstract}
This research aims to explore historical consciousness among young generation or millennial generation especially those students of Universitas Negeri Jakarta, to describe how their sociocultural has created their historical consciousness. This research was conducted at Universitas Negeri Jakarta using qualitative naturalistic design. The result of research shows the majority of informant understands the purpose of history learning. History learning is also believe to be a solution to national problem. Through historical consciousness someone should learn from his history and appreciate himself as part of the nation. More than half of informant said that radicalism phenomena today had been caused by low level of historical consciousness. In order to deal with the incessant influence of globalization the informant has several efforts such as understanding the situation in community, building tolerance among citizen, ready to maintain the political stability of Indonesia, mutual cooperation, rebuilding the character of Indonesian nation, introducing the importance of learning history to student, stem the inflow of information and film with foreign cultural nuances. The student as millennial generation used to access information and communication technology which is influencing their point of view of foreign culture and tend to receive information without critics. Nevertheless, they understand that one factor that threatens the nation culture is globalization. Therefore as young generation, they must have their positioning in the middle of globalization wave. Effort can be made to foster historical consciousness are reading objective reference book, respecting others, building tolerance and imitating national figures and heroes as an example.
\end{abstract}

Keywords-Industrial Revolution 4.0, Millennial Generation, Globalization, Historical Consciousness

\section{INTRODUCTION}

Globalization coupled with rapid technological development today has brought the world into the industrial revolution era 4.0. Industrial revolution 4.0 is marked by advances in digital technology, artificial intelligence, internet of thing, big data and robotization. Students now included in the Millennial Generation must be able to face the era of digitalization, so that it cannot cause a negative project. One effort to solve the problem must have a high historical consciousness

Consciousness is often referred to by some parties in Indonesia with various objectives, but few researchers have studied it in depth, for example, conducting research in SMAN 1 Yogyakarta about the actualization of the values of historical consciousness and nationalism in the learning of history[1]. In his research, it was produced that the actualization of historical consciousness values in the historical context historical heritage of the nation.

Such conditions in Indonesia are not the only one, in Canada the concept of historical consciousness emerged only in 2001 at a symposium entitled "Theorizing Historical Consciousness"[2]. As a concept, historical consciousness can be traced back to Hans-Georg Gadamer in 1963 which was then passed on by German educators Karl-Ernst Jeismann in 1977 and Jorn Rusen in 1987[2].

Millennial generation is a group of teenagers who always hold their cellphones. According to social researchers, millennial are those whose ages range from 15 to 34 years or those born between 1980 and 2000. The results of a study conducted by Boston Consulting Group concluded that the characteristics of Generation Y (Millennial Generation) are; (1) User Generated Content (UGC), (2) Millennial must have a social media account as a communication tool and information center, (3) Conventional reading interest decreases and prefers to read via smartphone, (4) Millennial would prefer cellphones rather than television and (5) Millennial make families the center of their judgment and decision makers.

According to Karl Ernst Jeismann and Jorn Rusen, historical consciousness is a consequence of history learning as a metacompetence learning from thinking historically for someone

\section{RESEARCH METHODS}

This research was conducted at the Universitas Negeri Jakarta and focused on getting an overview of understanding historical consciousness among the millennial. The 
research was carried out using qualitative naturalistic design, so that it was expected to reveal a variety of qualitative information with careful and meaningful analysis descriptions. At each object will be seen the tendency, mindset, disorder, and appearance of behavior and its integration as in the genetic case study [3]. Because the problems and research focus have been determined before taking field data, this type of research strategy can be more specifically referred to as embedded study research [4].

The source of the research data is the students of Universitas Negeri Jakarta. Data collection was done through in-depth interview techniques, non-participant observation, and document records. The sampling technique was carried out by purposive sampling. To guarantee the validity of the data collected, the informant review technique was used. Data analysis techniques use interactive analysis models which include data reduction activities, data presentation, verification, and conclusion drawing. In the process, it is carried out in an interactive form as a process that continues, repeats, and continues to form a cycle [5].

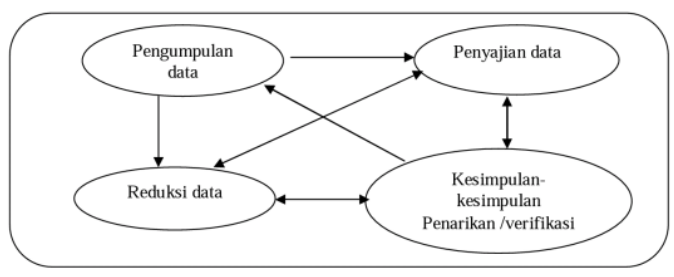

Figure 1. Data analysis component Interactive Model

\section{RESULTS AND DISCUSSION}

A. Appreciate the meaning and essence of history for the present and future

Appreciate the meaning and essence of history for the present and the future is an important part of historical consciousness. This is related to the historical dimension of time, the past, present and future. Not only that by appreciation the meaning and essence of history, but one will be able act according to its historical consciousness. One way to appreciate the meaning and essence of history is to understand the purpose of studying history.

The results of the study show that $85 \%$ of millennial university students, understand the purpose of history learning, namely to understand important events, shape the identity of society to be better. History can be used as a guideline for the nation, by learning history can organize the better future. History learning is also believed to be able to be a solution to the national problem by understanding the purpose of studying history. history teaches us to have a perspective and critical thinking, so that we become human beings who have historical consciousness so that when they become teachers they will become educational pioneers who humanize humans. To understand and appreciate the history of the nation, think historically and critically so that previous events will not be repeated in the future or at least know how to anticipate past mistakes and maintain the integrity of the Republic of Indonesia.

Informants understand that learning history makes a person wiser in acting, being a tolerant human being and Unity in Diversity. Learning history can also improve one's own life by referring to past events to be useful lessons for the future, awareness in human beings to know the origin of themselves and the events they experienced themselves. Understand and appreciate the history of his people. Through learning history can at least know how to anticipate past mistakes.

Based on the results of these studies indicate that most of the informants have historical consciousness when viewed from the indicator to appreciate the meaning and essence of history for the present and the future. Of course this is something positive considering that the millennial generation is a more advanced generation than the previous generation. Historical consciousness has certainly made millennial capable of supporting the development of the nation, especially because millennial have a high work ethic and are prepared to face a technology-oriented future [6], [7].

\section{B. To know himself and his nation}

Historical consciousness gives ability to someone to know himself and his nation. Through historical consciousness someone should learn for his history and appreciate himself as part of the nation. The disability to understand that he is part of the nation will make problems such as radicalism. Radicalism can grow rapidly as rapid as information and communication technology more advance. Through recent technology that is internet proof to became the easiest and most effective way to spread radicalism [8]. One characteristic of millennial is the ability to operate information and communication devices. This cause increasingly opens more access for information rapidly and widely, which bring various consequences both positive and negative. The majority of informant (75\%), said that radicalism phenomena today had been caused by low level of historical consciousness. The low level of historical consciousness had caused radicalism in the absence of history knowledge of his own nation. Moral degradation among youngster today can be seen as they more favourability to foreign culture and underestimate to Indonesian indigenous culture.

Millennial generation have high awareness for using information and communication technology. The fast and rapid of information influence their point of view for foreign culture so that they tend to absorb all information without any critics [9]. Later this will cause further erode to personal identity so 
that radicalism will develop. The result of the research show that the majority of informant understand the function of historical consciousness as personal identity amplifier, filtering bad influence of foreign information.

\section{History for fostering national culture}

One factor that threatens the preservation of national culture is globalization. Although it does not mean that globalization only has a negative impact on national culture, it depends on how each individual understands and responds to the influence of globalization. So that it becomes a necessity for the current generation to be able to position itself in the situation and conditions in the midst of globalization which has a profound influence on the development of national culture. In order to deal with the incessant influence of globalization, informants chose several efforts that could be done, namely: (1) understanding the situation that occurred in the community $(22.5 \%)$; (2) building tolerance among fellow citizens of different religions, ethnicities, cultures, educational levels and economic conditions (30\%); (3) ready to maintain the political stability of the Republic of Indonesia (15\%); (4) mutual cooperation (5\%); (5) rebuilding the character of the Indonesian nation $(15 \%)$; (6) introducing the importance of learning history to students $(7.5 \%)$; (7) stem the inflow of information and films with foreign cultural nuances $(5 \%)$.

As a student, the efforts that can be done by informants to foster historical consciousness is by studying history through reading reference books that are considered objective, respecting others, building tolerance, rejecting SARA's actions, and imitating figures and national heroes. The informants believe that having a historical consciousness can have values of character and honesty, and motivate themselves to act historically in order to improve themselves.

Based on the options chosen, tolerance is one of the most dominant ways believed to be an effort to anticipate the effects of globalization. As a generation born in diversity, the millennial generation has a high awareness of diversity [10], appreciates cultural impact and is socially more receptive to broad culture[11]. If viewed from the point of view of the Indonesian people, Bhinneka Tunggal Ika is a philosophy of diversity. The Indonesian nation has a long history of unity and diversity, even Indonesia is built on this diversity.

\section{CONCLUSION}

The millennial generation is a more advanced generation than the previous generation. Awareness of working together is the greatest strength that the millennial generation has as a characteristic, besides that it also has a sense of tolerance for high diversity. An understanding of the use of information and communication technology, makes this generation more often interact with information that can be accessed easily and on a wider scale. This makes the millennial generation in a more vulnerable position in the face of globalization and the rise of radicalism. So that historical consciousness becomes an important provision in facing the challenges of a fast-paced era.

Through research results can show that the millennial generation, has a historical consciousness that can be seen from the indicator of appreciation of the meaning and essence of history for the present and the future, indicated by an understanding of historical goals and the importance of studying history for the future. Millennial show a high level of tolerance, and realize that tolerance for diversity is an important effort in facing the incessant globalization. Historical consciousness is considered important as one of the provisions in criticizing information flows that are increasingly fast and broad.

\section{REFERENCES}

[1] Aman, "Kesadaran Sejarah dan Nasionalisme: Pengalaman Indonesia," INFORMASI, no. 2, pp. 1325, 2009.

[2] C. Wallace-casey, "“ I like to take everything and put it in my own words ': Historical Consciousness , Historical Thinking, and Learning with Community History Museums," Can. J. Educ. / Rev. Can. l'éducation, vol. 40, no. 1, pp. 1-28, 2017.

[3] Muhadjir, Noeng, 2002. Metodologi Penelitian Kualitatif Edisi IV. Yogyakarta: Penerbit Rake Sarasin.

[4] Yin, Robert K. (2009). Studi Kasus: Desain dan Metode. Jakarta: Penerbit RajaGrafindo Persada.

[5] Miles, M.B. Huberman. A.M. , dan Saldana J. (2014). Oualitative Data Analysis, A Methods Sourcebook, Edition 3. USA: Sage Publications. Terjemahan Tjetjep Rohindi, UI-Press

[6] K. K. Myers and K. Sadaghiani, "Millennials in the workplace: A communication perspective on millennials' organizational relationships and performance," J. Bus. Psychol., vol. 25, no. 2, pp. $225-238,2010$.

[7] J. Eckleberry-Hunt and J. Tucciarone, "The challenges and opportunities of teaching 'generation y'.," $J$. Grad. Med. Educ., vol. 3, no. 4, pp. 458-61, 2011.

[8] N. N. Hasim, H. Mohamed, and J. Ibrahim, "The Effect and Challenges of Online Radicalization on Modern Day Society," Int. J. Inf. Commun. Technol. Res., vol. 6, no. 12, 2016

[9] A. Taylor, "A study of the information search behaviour of the millennial generation," Inf. Res., vol. 17 , no. 1,2012

[10] S. Keeling, "Advising the Millennial Generation," NACADA J., vol. 23, no. 1-2, pp. 30-36, 2003.

[11] M. Monaco and M. Martin, "The Millennial student: A new generation of learners," Athl. Train. Educ. J., vol. 2, no. 2, pp. 42-46, 2007. 
